Original Research Paper

\title{
Biological Activity of Lactic Acid Based Feed Additive and its Physiological Effect on the Animal Organism
}

\author{
Nadezhda Nikolaevna Lantseva, Alexander Nikolaevich Shvydkov, \\ Lyudmila Anatolyevna Ryabukha and Veronica Valeryevna Evsyukova \\ Novosibirsk State Agrarian University, 630039, Russia, Novosibirsk, Dobrolyubova Str., 160, Russia
}

\author{
Article history \\ Received: 09-03-2018 \\ Revised: $18-07-2018$ \\ Accepted: 02-10-2018 \\ Corresponding Author: \\ Nadezhda Nikolaevna Lantseva \\ Novosibirsk State Agrarian \\ University, 630039, Russia, \\ Novosibirsk, Dobrolyubova \\ Str., 160, Russia \\ Email: n.n.lantseva@yandex.ru
}

\begin{abstract}
The data obtained as a result of the study of the enzymatic activity of the lactic acid based feed additive LAFA, based on various bacteria, are consistent with the results of the research presented in the publications on the matter, concerning the fact that probiotic bacteria have enzymatic activity. The conducted studies revealed the leading enzymatic properties of bifidobacteria in the composition of LAFA, in comparison with other investigated microorganisms. Various strains of bifidobacteria constitute, according to some sources, up to $90 \%$ of the representatives of the normal flora of poultry intestine. Bifidobacteria are found in all parts of the intestine. All the detected enzyme groups synthesized by them, thus, participate in all enzymatic processes in the processing of feed in the gastrointestinal tract. The results of the study on determining the concentration of human interferon-alpha-2 in the intestine of laboratory mice when fed with LAFA, based on bifidobacteria, lactobacilli, propionic acid bacteria and lactic thermophilic streptococcus, showed the stimulating effect of the additive on the production of interferon in the intestine of the mice. The greatest stimulating effect on the production of interferon was obtained from the LAFA based on Lactobacilli (LAFA-L) and bifidobacteria (LAFA-B). It is these types of microorganisms (lactobacilli and bifidobacteria) that are dominant, irreplaceable and useful in the intestines of animals and poultry. The studies on determining the antibiotic susceptibility of opportunistic pathogenic strains in the presence of LAFA showed a general tendency of increase in the antibiotic susceptibility of the studied strains of microorganisms after cultivation with LAFA based on monocultures of probiotic microorganisms, with a simultaneous decrease in the number of cultures with low susceptibility and an increase in the number of the susceptible ones with an increase in the period of their cultivation. However, the determination of the degree of antibiotic susceptibility (change in the zone of growth retardation of microorganisms) of a conditionally pathogenic microflora revealed the absence of such a pattern.
\end{abstract}

Keywords: Lactic Acid-Based Feed Additive, Functional Properties, Microbiological Composition, Chemical Composition

\section{Introduction}

The article deals with the study of biological activity of lactic acid based feed additive and its physiological effect on animal organism. It is revealed that different probiont microorganisms used in the same laboratory change qualitatively and quantitatively the basic parameters of the final product of lactic acid based feed additive. Investigated properties of the lactic acid based feed additive are similar to the properties of the gastrointestinal microflora, with only difference in the quantitative and qualitative composition. Small and ultra small doses of bioeffecting agents of lactic acid based feed additive can be used to create temporary microbiocenosis, activate similar properties and capabilities of the animal body, develop an adaptation 
mechanism, which is the basis of the normal functioning

The most important task of the agro-industrial complex consists in providing the food processing industry with high-quality raw materials, while the population - with environmentally friendly food products produced using new ecologically sound technologies. A distinctive feature of all preparations designed to replace antibiotics is their environmental safety. These preparations include first of all probiotics, prebiotics, symbiotics, detoxicants, organic acids, etc., obtained using various biotechnologies (Kobzeva et al., 2013; Lantseva et al., 2013a; 2013b; Shkil' et al., 2014; 2016; Shvydkov et al., 2013a; 2013b; 2013c; 2015a).

Efficient feeding of agricultural animals requires preparations alternative to antibiotics that have antimicrobial growth promoting properties and provide antiviral protection of animal organism. The solution of this problem is especially important for poultry industry. Such preparations should be absolutely harmless, not deposited in the body and possess at the cellular level such an action mechanism, in which the genetic resistance of pathogenic microorganisms is impossible. These requirements are met by probiotics (Chebakov et al., 2014; Kobtseva et al., 2014; Lantseva et al., 2016; Shvydkov et al., 2014a; 2014b; 2015b; 2016; Ryabukha et al., 2015).

The research goal is to evaluate the bioefficiency of lactic acid based feed additive and its physiological effect on animal organism.

\section{Methods}

Studies of lactic acid-based feed additive (hereinafter LAFA) were carried out in various laboratories. Probiotic LAFA is produced according to TU 9224-0010141853476-08. The assortment of the LAFA is determined both by individual capabilities of probiotic cultures and properties acquired in symbiosis with each other. The LAFA is a product containing live probiont microorganisms and their metabolic byproducts.

Studies of the chemical composition of the LAFA were conducted at the Laboratory of the Siberian Federal Scientific Center of Agrobiotechnologies of the Siberian Branch, Russian Academy of Sciences. For the chemical analysis of the LAFA, industrially produced product was sampled in the amount of 200 grams. In the course of study the following parameters were considered: The initial moisture measured by drying at $65^{\circ} \mathrm{C}$; calculated total moisture; crude protein determined by Kjeldahl method; crude fiber determined by Hennebery and Stoman methods; crude ash determined according to ashing technique by combustion in a muffle furnace at $500-550{ }^{\circ} \mathrm{C}$; crude fat determined by Papadopoulos method; nitrogen-free extract determined by calculation method; phosphorus determined by photoelectric of the entire biological system. colorimetric method; calcium determined by volumetric titration; and vitamins of B, E, A group determined according to the established procedures of Lebedev.

To conduct microbiological analysis of serial batch of LAFA-LB (Lactobacillus acidophilus and Bifidobacterbifidum longum), the preparation was sampled in amount of $100 \mathrm{~mL}$. Microbiological studies were conducted on anti-plague station at FSBEI Medical Sanitary Station No.163. Coliform bacteria were determined according to GOST 31747-2012; E. coli were determined according to GOST 30726-2001; S. aureus were determined according to GOST 31746-2012; yeast and mold fungi were determined according to GOST 10444.12-2013; pathogens including salmonella were determined according to GOST 31659-2012; lactobacilli were determined according to GOST R 51331-99 and MUK 4.2.999-00; and bifidobacteria were determined according to GOST R 51331-99 and FLOUR 4.2.999-00.

Studies on the presence and concentration of organic acids were carried out at the Chemistry Department of Biysk Technological Institute of FSBEI of Higher Education "Polzunov Altai State Technical University" using the capillary zone electrophoresis method.

Studies to determine the enzymatic activity of the LAFA on the basis of various bacteria were carried out in four stages at the Central Microbiological Laboratory of the Sibbiofarm plant. Samples of the LAFA based on monocultures of the LAFA-B (Bifidobacterbifidum longum), LAFA-S (Streptococcus termophilus), LAFA-P (Propionibacterium acidi-propionicum) and LAFA-L (Lactobacillus acidophilus) were selected for the study. At the first stage, the method according to GOST 20264.4-89 "Enzyme preparations. Methods for the determination of amylase activity" was used. The total amylolytic activity was measured in all LAFA samples by Anson method. At the second stage the method in accordance with GOST 20264.2-88 "Enzyme Preparations. Methods for determination of proteolytic activity" was applied. The total Proteolytic Activity (PA) in the studied samples was determined. At the third stage the method based on TU9291-008-13684916-05 was used. The total Cellulolytic Activity (CA) was determined in all presented LAFA samples. The last fourth stage was determining the Lipase Activity (LA) by Skerman method.

The study of the LAFA effect on the sensitivity of opportunistic pathogenic bacteria and pathogenic microorganisms to antibiotics was determined by the disk diffusion test method according to the methodological guidelines for the bacteriological diagnosis of mixed intestinal infection of young animals caused by pathogenic enterobacteria (1999). The test was performed at the state scientific institution "Institute of Experimental Veterinary Science of Siberia and the Far East" of the Siberian Branch, Russian Academy of Agricultural Sciences. 
Table 1: Research scheme of the LAFA functional properties

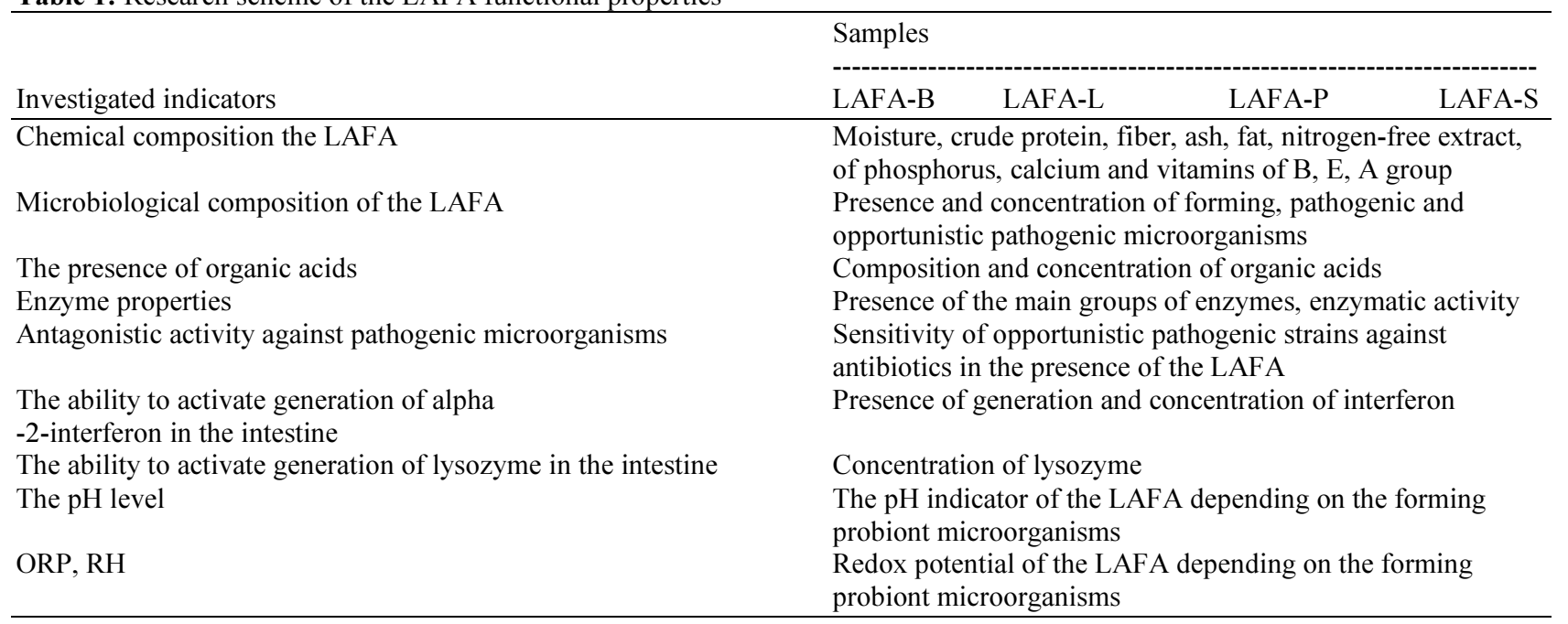

Studies to determine the stimulatory effect of the probiotic on the production of human interferon $\alpha-2$ in intestine of laboratory mice when feeding with various probiont microorganisms was carried out in the LLC Scientific and Production Company "Research Center" in Koltsovo of the Novosibirsk Region. Five samples were prepared and selected for the experiment. The experiments on determination of concentrations of alpha- 2 and murine interferon in the investigated samples according to immunoenzymometric and biological methods were performed on a vertical multichannel spectrophotometerfluorimeter FL-600. Lysozyme activity was determined by lysis of the culture on Petri dishes with nutrient agar. The lysozyme activity was determined using a culture of the Micrococcus lysodeikticus microorganism.

The study of $\mathrm{pH}$ level and Oxidation-Reduction Potential (ORP) of the LAFA was carried out using an electronic device "Nitron-pH" according to the INC.400.00.000 PE methodology.

The test object was a lactic acid feed additive based on probiont microorganisms of the LAFA-B (Bifidobacterbifidum longum); LAFA-S (Streptococcus termophilus); LAFA-P (Propionibacterium acidipropionicum); LAFA-L (Lactobacillus acidophilus); MKDSL (Streptococcus termophilus, Lactobacillus acidophilus); and LAFA-BSPL (based on all investigated cultures of microorganisms). The research scheme of the functional properties of the LAFA (produced by individual entrepreneur "Chebakov V.P.") is presented in Table 1 depending on the formative probiont microorganisms.

\section{Results}

Chemical analysis of the LAFA based on different monocultures (L, B, P and S) and symbiotics (LS, LBPS) showed that at the same humidity, all the LAFAs had almost the same level of protein within the range of 2.78-
$3.0 \%$. The highest level of fat had the LAFA-Bequal to $0.32 \%$, therefore the contribution of bifidobacteria to the fat level was significant. This indicator in monocultures varied within in the range of $0.14-0.18$, while in the LAFA-LBPS it was $0.20 \%$. Ash level in the studied LAFAs was the same and changed within the range of $0.73-0.77 \%$. Monocultures based LAFAs had the same level of nitrogen-free extract equal to $5.38-5.62 \%$, whereas symbiotics of the LAFA-LS and LAFA-LBPS had higher values equal to $6.00-6.34 \%$. The level of calcium and phosphorus content in all studied LAFAs was almost the same, namely $0.12-0.14 \%$ of calcium and $0.08 \%$ of phosphorus. The content of amino acids, except for alanine and arginine, in the LAFA-B was higher than in the rest of the studied cultures that was confirmed by literary sources.

The LAFA-B also had a higher level of vitamins. Content of vitamin A in the LAFA-B equaled to 0.26 $\mathrm{mg} / \mathrm{kg}$, while in other LAFAs this figure was 0.19-0.21 $\mathrm{mg} / \mathrm{kg}$. Content of vitamin $\mathrm{E}$ in the LAFA-B equaled to $0.88 \mathrm{mg} / \mathrm{kg}$, while in the remaining additives it was equal to $0.63-074 \mathrm{mg} / \mathrm{kg}$. The content of B group vitamins in the LAFA-B was of a higher level compared to other LAFAs. Thus, the content of vitamin $B_{1}$ in the LAFA-B was 0.44 , while in other LAFAs - 0.314-0.36 mg/ $\mathrm{kg}$. The level of vitamin $\mathrm{B}_{2}$ in the LAFA-B was 1.32 , while in the other LAFA sit was $0.96-1.15 \mathrm{mg} / \mathrm{kg}$. The content of vitamin $\mathrm{B}_{3}$ in the LAFA-B was 3.86, in other LAFAs $-2.79-3.29 \mathrm{mg} / \mathrm{kg}$. The content of vitamin $\mathrm{B}_{5}$ in the LAFA-B was also higher than that in other LAFAs and equaled tol.31versus $0.93-1.12 \mathrm{mg} / \mathrm{kg}$. The greatest difference was noted in the content of vitamins $B_{6}$ and $\mathrm{B}_{12}$ in the LAFA. Thus, the content of $\mathrm{B}_{6}$ in the LAFA-B was 1.77 , while in other samples of the LAFA it was $1.26-1.43 \mathrm{mg} / \mathrm{kg}$. Vitamin $\mathrm{B}_{12}$ contained in the LAFA-B amounted to $29.33 \mathrm{mg} / \mathrm{kg}$ that was much higher than its amount in other LAFAs equal to $21.92-24.97 \mathrm{mg} / \mathrm{kg}$. 
Table 2: Microbiological study of the LAFA-LB

\begin{tabular}{llll}
\hline & Defined indicator & Findings of investigation & Hygienic standard \\
\hline 1 & Coliform bacterias & Absent & Not allowed in $1.0 \mathrm{~g}$ \\
2 & E. coli & Absent & Not allowed in $10.0 \mathrm{~g}$ \\
3 & S. aureus & Absent & Not allowed in $1.0 \mathrm{~mL}$ \\
4 & Yeast and mold fungi & Absent & Not allowed in $25.0 \mathrm{~g}$ \\
5 & Pathogens including salmonella & Absent & No less than $10^{6} \mathrm{CFU} / \mathrm{ml}$ \\
6 & Lactic bacteria & $7 \times 10^{6}$ & No less than $10^{6} \mathrm{CFU} / \mathrm{ml}$ \\
7 & Bifidobacteria & $10^{6}$ & \\
\hline
\end{tabular}

The results of microbiological composition of the LAFA are presented in Table 2.

The level of the content of forming microorganisms in the LAFA may vary within the range of $10^{6}$ $10{ }^{11} \mathrm{CFU} / \mathrm{ml}$.

In consequence of the quantitative composition analysis of organic acids, it was revealed that all studied probiotic additives had different concentrations of lactic acid ranging from $6370.5 \mathrm{mg} / \mathrm{dm}^{3}$ in the LAFA-B to a maximum value of $27105 \mathrm{mg} / \mathrm{dm}^{3}$ in the LAFA-S. The main producer of acetic acid was bifidobacteria -2500 $\mathrm{mg} / \mathrm{dm}^{3}$. The LAFA-S and LAFA-L contained about the same amount of citric acid in amount of 864.4 and $857.5 \mathrm{mg} / \mathrm{dm}^{3}$, respectively. The LAFA-B consisted of $68.6 \mathrm{mg} / \mathrm{dm}^{3}$ of citric acid. Propionic acid was detected in the LAFA-P and LAFA-B in the amount of 108 and $45.25 \mathrm{mg} / \mathrm{dm}^{3}$, respectively. Butyric acid was revealed in two studied samples, namely the LAFA-L at a concentration of $146 \mathrm{mg} / \mathrm{dm}^{3}$ and the LAFA-P at a concentration of $76.69 \mathrm{mg} / \mathrm{dm}^{3}$.

Organic acids are used not only to protect against microbial contamination.

Acetic acid is effective against yeast, mold and intestinal opportunistic pathogenic bacteria and pathogenic bacteria.

Propionic acid is an inhibitor of yeast and mold and is the base of fungicidal preparations. At high concentrations it is used as an antibacterial preparation against gram-negative bacteria. It is used as a preservative and reduces the buffer capacity of the feed.

Lactic acid is effective against gram-negative bacteria, E. coli, Salmonella. It has a probiotic property, antiseptic effect and reduces the buffer capacity of feed.

Butyric acid promotes the growth and restoration of the villi of intestinal surface.

Citric acid has pronounced antibacterial properties, it improves energy metabolism in the Krebs cycle and activates it that contributes to the acceleration of metabolism.

Organic acids contained in the LAFA have both ecological and physiological effects in the poultry's intestines. Butyric and propionic acids are more conducive to the recovery of the intestinal epithelium and growth of the villi. This, in turn, provides a large surface of lepidic tissue of the intestinal mucosa for the attachment and functioning of normal microflora. Propionic acid has the greatest inhibitory effect on mold fungi. All organic acids have antibacterial activity against opportunistic and pathogenic bacteria.

Organic acids are growth factors for normal flora, creating temporary microbiota. The presence of the investigated organic acids in the LAFA allows using the LAFA both in the form of monocultures and in their combinations to obtain the necessary physiological or technological effect.

When studying the enzymatic activity of the LAFA on the basis of various probiont microorganisms, it was revealed that all studied LAFAs contained one or more enzymes' groups (Table 3). Thus, the LAFA-B showed the presence of all the studied enzyme groups. The LAFA-P contained in its composition three groups of enzymes: Amylolytic, proteolytic and cellulolytic. Three groups of enzymes were also found in the LAFAL, which contained proteolytic, cellulolytic, lipolytic and weakly expressed amylolytic group. The LAFA-S had in its composition two groups of enzymes: Proteolytic and cellulolytic, while amylolytic and lipolytic activity was expressed weakly.

The findings of investigation of the enzymatic activity of the LAFA based on various bacteria agree with the literature data that probiont bacteria possess enzymatic activity. Our research identified leading enzymatic properties of bifidobacteria in the composition of the LAFA compared to the other investigated microorganisms. According to some reports, normoflora of the poultry's intestine by $90 \%$ consists from various strains of bifidobacteria. Bifidobacteria are located in all parts of the intestine. The enzyme groups synthesized by these bifidobacteria are involved in all enzymatic processes for transformation of feed nutrients in the gastrointestinal tract. Bifidobacteria are actively involved in the processes of enzymatic digestion of feed, enhancing the hydrolysis of proteins. They ferment carbohydrates, hydrolyze fats and dissolve fiber. All the bacteria studied in the composition of the LAFA showed a certain degree of enzymatic activity. The obtained data indicate the specificity of the level and spectrum of enzyme groups produced, depending on the belonging of microorganisms to certain types and their vital activities. These data, together with other characteristics, should be taken into account when developing various recommendations for the use of certain types of probiotic feed additives. 
Table 3: Enzymatic activity of the LAFA (unit/ml)

\begin{tabular}{lllll}
\hline Sample of LAFA & Amylolytic activity & Proteolytic activity & Cellulolytic activity & Lipolytic activity \\
\hline LAFA-L & - & 1.0 & 72.40 & 1.4 \\
LAFA-S & - & 2.5 & 66.70 & - \\
LAFA-B & 11.2 & 2.0 & 66.70 & 12.6 \\
LAFA-P & 9.4 & 7.5 & 64.46 & - \\
\hline
\end{tabular}

The study of the growth dynamics of antibiotic susceptibility of microorganisms under the influence of the LAFA-S supernatant revealed a slight decrease by $4.1 \%$ in the sensitivity of Ent. Fecalis on the $1^{\text {st }}$ day of the study, by $8.1 \%$ - of Pr. Vulgaris, by $12.8 \%$ - of $K l$. Pneumoniae, with their subsequent growth on the $10^{\text {th }}$ day $(17.4 ; 29.0$; and $34.1 \%)$, the $20^{\text {th }}$ day $(40.5 ; 42.1$; and $83.5 \%)$ and the $30^{\text {th }}$ day $(57.2 ; 72.1 ; 90.3 \%)$, respectively. An increase in antibiotic susceptibility was also revealed in St. Albus, Sal. Dublin, E. coli on the $1^{\text {st }}$ day (from 17.6 to $23.7 \%$ ), on the $10^{\text {th }}$ day (from 29.1 to $67.1 \%$ ), on the $20^{\text {th }}$ day (from 0 to $60.0 \%$ ), on the $30^{\text {th }}$ day (from 67.0 to $73.0 \%$ ) comparing with control groups. When cultivating strains of opportunistic pathogenic microflora with the LAFA-L supernatant, we noted a decrease in antibiotic susceptibility on the $1^{\text {st }}$ day of incubation in Ent. Fecalis by $1.1 \%$, in Sal. Dublin - by $13.3 \%$, in Pr. Vulgaris - by $16.8 \%$ and in $\mathrm{Kl}$. Pneumoniae- by $31.4 \%$. At that, an increase by $13.6 \%$ was revealed in St. Albus and by $14 \%$ in E. Soli. The $10^{\text {th }}, 20^{\text {th }}$ and $30^{\text {th }}$ days showed the growth of antibiotic susceptibility in Ent. Fecalis (by 26.3; 42.3; and $60.0 \%$ ), in Sal. Dublin (by 43.3; 45.0; and 65.0\%), in Pr. Vulgaris (by 49.2; 70.0; and 90.0\%), respectively. Also, an increase in antibiotic susceptibility was revealed in St. Albus, E. coli from 13.6 to $14.0 \%$ on the $1^{\text {st }}$ day, from 26.2 to 53.0 on the $10^{\text {th }}$ day, from 17.0 to 54.0 on the $20^{\text {th }}$ and from 65.1 to $78.4 \%$ on the $30^{\text {th }}$ day.

When incubating the LAFA-P supernatant with strains of opportunistic pathogenic microflora, a decrease in antibiotic susceptibility by $13.6 \%$ was found in St. Albus on the $1^{\text {st }}$ day of the study that was followed by the growth on the $10^{\text {th }}$ day (by $23.5 \%$ ), on the $20^{\text {th }}$ day (by $2.0 \%$ ) and on the $30^{\text {th }}$ day (by 65.3\%). An increase in antibiotic susceptibility was found when cultivating Ent. Fecalis, Sal. Dublin, E. coli, Pr. Vulgaris and Kl. Pneumoniae on the $1^{\text {st }}$ day of the study (from 1.4 to $26.0 \%$ ), on the $10^{\text {th }}$ day (from 5.4 to $57.0 \%$ ), on the $20^{\text {th }}$ day (from 2.0 to $42.5 \%$ ) and on the $30^{\text {th }}$ day (from 56.0 to $66.4 \%$ ), respectively.

When cultivating the LAFA-B supernatant with the studied microorganisms, an increase in antibiotic susceptibility during the entire study period was noted in Ent. Fecalis (from 18.0 to $53.0 \%$ ), St. Albus (from 2.0 to $73.2 \%$ ), Sal. Dublin (from 52.1 to $65.0 \%$ ), E. coli (from 38.0 to $71.0 \%$ ), Pr. Vulgaris (from 18.1 to $75.3 \%$ ) and Kl. Pneumoniae (from 25 to $79.3 \%$ ), respectively.

In consequence of the studies, a multidirectional impact of probiotics' supernatants on the dynamic pattern of antibiotic susceptibility of opportunistic pathogenic microorganisms was revealed. A significant growth of antibiotic susceptibility was noted on the $20^{\text {th }}$ and $30^{\text {th }}$ day in Kl. Pneumoniae when incubating with the supernatants of LAFA-S (by 83.5 and $90.3 \%$ ), LAFA-L (by 70.0 and $90.0 \%$ ), LAFA-P (by 42. 5and65.5\%) and LAFA-B (by 54.1 and $79.3 \%$ ).

The influence of the LAFA on the change in the quantitative indicators of antibiotic susceptibility of opportunistic and pathogenic microorganisms to several antibiotics showed a multidirectional influence of probiotic supernatants on antibiotic susceptibility in different microorganisms during different periods of the research. Thus, the impact of Str. Termophilus B-41 caused a decrease in the number of antibiotic-susceptible preparations in Ent. Fecalis on the $1^{\text {st }}$ day by $12.5 \%$, in E. coli - by $28.6 \%$ and in Pr. Vulgaris - by $62.5 \%$; on the $10^{\text {th }}$ day, in E. coli - by $18.2 \%$, on the $20^{\text {th }}$ day in Ent. Fecalis - by $13.3 \%$, in Pr. Vulgaris- by $14.3 \%$. Incubation with the same probiotic revealed an increase in the number of antibiotic- susceptible preparations in $S t$. Albus on the $1^{\text {st }}$ day of the study by $50.0 \%$, in $K l$. Pneumonia- by $50.0 \%$; in Sal. Dublin- by $100.0 \%$; on the $10^{\text {th }}$ day in St. Albus - by $14.3 \%$; in Sal. Dublin- by $16.6 \%$; in Kl. Pneumoniae - by $57.1 \%$; on the $20^{\text {th }}$ day, in E. coli - by $12.5 \%$; in Sal. Dublin - by $30.0 \%$, in St. Albus - by $50.0 \%$; on the $30^{\text {th }}$ day the growth was noted in all samples of opportunistic pathogenic microflora (Ent. Fecalis, St. Albus, Sal. Dublin, E. coli, Pr. Vulgaris and Kl. Pneumoniae) from 6.2 to $63.6 \%$.

When incubating the supernatant LAFA-L, an increase in antibiotic susceptibility was revealed on the $1^{\text {st }}$ day of the study in St. Albus, E. coli, Sal. ublin (up to $100.0 \%$ ); on the $10^{\text {th }}$ day -in St. Albus, E. coli and Pr. Vulgaris (from 9.1 to $50.0 \%$ ); on the $20^{\text {th }}$ day -in St. Albus, Sal.ublin, E. coli and Kl. Pneumoniae (from 20.0 to $62.5 \%$ ); and on the $30^{\text {th }}$ day in Ent. Fecalis, St. Albus, Sal. ublin, E. coli and Kl. Pneumonia (from 7.1 to $30.0 \%$ ). There was also a decrease in antibiotic susceptibility on the $1^{\text {st }}$ day of the study in Ent. Fecalis, Pr. Vulgaris and Kl. Pneumoniae (from 25.0 to $62.5 \%$ ); on the $10^{\text {th }}$ day -in Ent. Fecalis and St. Albus (from 11.1 to $58.3 \%$ ); and on the $20^{\text {th }}$ day -in Ent. Fecalis and Pr. Vulgaris (from 21.4 to $26.6 \%$ ).

During the cultivation of the LAFA-P supernatant, the growth of antibiotic susceptibility throughout the study was revealed in St. Albus (from 14.3 to $37.5 \%$ ), in Sal. Dublin (up to $150.0 \%$ ), in E. coli (from 0 to $16.6 \%$ ) and in Kl. Pneumoniae (from 50.0 to $133.3 \%$ ). At the same time, after incubation by the same probiotic, the decline in antibiotic susceptibility was noted on the $1^{\text {st }}$ 
day of the study in Pr. Vulgaris $(12.5 \%)$, on the $10^{\text {th }}$ day - in Ent. Fecalis (6.6\%) and Pr. Vulgaris (14.3\%).

After incubation of the LAFA-B supernatant, the growth of antibiotic susceptibility was revealed throughout the study in St. Albus (from 14.3 to 41.6\%), Sal. Dublin (from 0 to $63.6 \%$ ), E. coli (from 9.1 to $25.0 \%$ ) and Kl. Pneumoniae (from 60.0 to $71.4 \%$ ). There was also a slight decrease in antibiotic susceptibility on the $20^{\text {th }}$ day of the study in Ent. Fecalis (6.6\%) and Pr. Vulgaris (14.3\%).

The dynamic pattern in the number of preparations to which antibiotic susceptibility of the opportunistic pathogenic microflora was revealed under the impact of probiotics showed a multidirectional effect of microorganisms. The most pronounced effect on the change in antibiotic susceptibility was revealed in the LAFA-P and LAFA-B supernatants. Probiotic strains of microorganisms produce a number of bacteriocins that inhibit the growth of pathogenic and opportunistic pathogenic microorganisms, as well as pathogens of acute intestinal infections. Thus, the bacteria produce nisin, which is effective against grampositive Clostridium and diplokokc in effective against Staphylococcus aureus. In addition, lactobacilli produce laktokokcin, which depresses reproduction of Streptococcus areus, Listeria monocitogenes, Clostridium perfringes, Salmonella typhimurium, etc.

Studies of the concentration of alpha-2 interferon obtained by the Enzyme-Linked Immunosorbent Assay (ELISA) showed that the lactobacilli based LAFA-L sample was comparable with the control sample. Sample of the LAFA-S based on lactic acid thermophylic streptococcus showed that the concentration of alpha-2interferon in the intestinal contents of the mouse was higher by $0.1806 \mathrm{pg} / \mathrm{ml}$ than that in control, while the concentration of interferon in the sample with the LAFA$\mathrm{P}$ based on propionic bacterium was lower by 0.15188 $\mathrm{pg} / \mathrm{ml}$ than in the control sample.

On the $2^{\text {nd }}$ day of the study, interferon concentrations in all experimental samples of homogenates were higher than similar indicators for the previous day. Control sample showed the concentration of interferon equal to $67.6572 \mathrm{pg} / \mathrm{ml}$. Maximal growth of $17.93566 \mathrm{pg} / \mathrm{ml}$ was observed in the sample of LAFA-B and was by $15.03422 \mathrm{pg} / \mathrm{ml}$ more than that noted on the $1^{\text {st }}$ day. The minimal growth of 2.81233 $\mathrm{pg} / \mathrm{ml}$ was observed in the sample of LAFA-P that was by $0.6628 \mathrm{pg} / \mathrm{ml}$ more than that noted on the $1^{\text {st }}$ day.

On the $3^{\text {rd }}$ day all the experimental samples showed growth in interferon concentrations compared to the data obtained on the $2^{\text {nd }}$ day, except of the LAFA-P, where the reduction amounted to $0.65672 \mathrm{pg} / \mathrm{ml}$. In the sample of LAFA-L the growth in the concentration of interferon comparing to the $2^{\text {nd }}$ day made up $3.20108 \mathrm{pg} / \mathrm{ml}$ that was more than that noted on the $2^{\text {nd }}$ day. In the LAFA-S the increase was $1.14336 \mathrm{pg} / \mathrm{ml}$, while in the sample of LAFA-B it made up $0.51250 \mathrm{pg} / \mathrm{ml}$.
On the $4^{\text {th }}$ day in the sample of LAFA-L, the content of interferon decreased by $0.93640 \mathrm{pg} / \mathrm{ml}$ comparing to the $3^{\text {rd }}$ day. During this day the concentration ratio of interferon maximally increased to $20.10371 \mathrm{pg} / \mathrm{ml}$ in the sample of LAFA-B, while comparing to the $3^{\text {rd }}$ day it increased by $1.65555 \mathrm{pg} / \mathrm{ml}$. Minimal increase of the interferon was noted in the group of the LAFA-P, equal to just $2.20813 \mathrm{pg} / \mathrm{ml}$. With regard to the $3^{\text {rd }}$ day it increased by $0.05252 \mathrm{pg} / \mathrm{ml}$. In the sample of LAFA-S the growth made up $18.00311 \mathrm{pg} / \mathrm{ml}$.

On the 5th day from the start of the experiment an increase in the interferon concentration in relation to the $4^{\text {th }}$ day was noted only in the sample of LAFA-P and amounted to $0.44669 \mathrm{pg} / \mathrm{ml}$. All experimental samples showed decrease in concentration as compared to previous figures. The greatest decrease was observed in the sample of LAFA-L and equaled to $3.82767 \mathrm{pg} / \mathrm{ml}$ comparing to the $3^{\text {rd }}$ day. The decrease in the level of interferon in the sample of LAFA-B was $16.57932 \mathrm{pg} / \mathrm{ml}$ that was by $3.52439 \mathrm{pg} / \mathrm{ml}$ less than noted on the previous day.

Analysis of the level of interferon obtained by the ELISA technique testifies about the positive effect of all the studied LAFAs on the concentration of interferon in the intestine of laboratory animals. Maximum concentration of interferon was observed on $3^{\text {rd }}$ and $4^{\text {th }}$ days in the samples of LAFA-L, LAFA-S and LAFA-B. Even on the $5^{\text {th }}$ day after intake of the LAFA by test mice the concentration of interferon was high enough.

Investigation of interferon concentration in samples obtained by the method of suppression of the virus cytopathic effect showed both an increase and a decrease in the concentration of interferon in the control and experimental samples (Table 4).

Search and use of preparations, particularly probiotics, able to produce and stimulate the production of pharmaceutical form of interferon in the intestine, is dictated by the need to protect drug substances against the degrading impact of proteolytic content of the mucosa of the gastrointestinal tract when taken orally. The investigated probiotic LAFAs and used strains of microorganisms studied in the present work stimulate the synthesis of interferon near target cells localized in the mucosa. Within a day after the start of feeding, all the studied LAFAs based on various microorganisms showed the ability to produce and stimulate the generation of interferon.

Table 4: Interferon concentration in the contents of the intestine, determined by the method of suppression of the cytopathic effect (MU/ml)

\begin{tabular}{llllll}
\hline Days & LAFA-L & LAFA-S & LAFA-B & LAFA-P & Control \\
\hline 1 & 0.0 & 0.98 & 0.00 & 0.0 & 25.8 \\
2 & 5.1 & 4.40 & 4.50 & 5.2 & 33.0 \\
3 & 4.7 & 4.60 & 4.06 & 4.9 & 31.9 \\
4 & 4.7 & 4.50 & 5.20 & 4.5 & 30.9 \\
5 & 5.8 & 5.20 & 4.70 & 4.7 & 36.8 \\
\hline
\end{tabular}


All the investigated bacteria monocultures in the composition of the LAFA contributed to the production of lysozyme in the mice intestine. The greatest impact on the level of lysozyme was caused by the LAFA-B, its value reached 212.3 units $/ \mathrm{ml}$. The lowest level of lysozyme equal to 104.8 units $/ \mathrm{ml}$ was found in homogenates of intestinal contents of mice receiving the LAFA-S.

The hydrogen ion concentration of all the LAFA samples studied within the temperature range from 10 to $35^{\circ} \mathrm{C}$ was stable and had small fluctuations. The $\mathrm{pH}$ level within this temperature range had changed by $2.3 \%$ (from 3.516 to 3.626 ) in the LAFA-L, by $5.17 \%$ (from 3.48 to 3.66 ) in LAFA-LS, by $4 \%$ (from 4.638 to 4.828 ) in LAFA-B and by $5.5 \%$ (from 4.494 to 4.744 ) in LAFA-P. The presence of lactic, citric and butyric acids in the LAFA-L and LAFA-LS makes these feed additives more acidic in comparison with the LAFA-B and LAFA-R, which contain propionic and acetic organic acids of predominantly alkaline nature.

Thus, the lactic acid feed additive based on bifidobacteria and propionic bacteria is ranged in the lower part of the $\mathrm{pH}$ scale as compared to the LAFA based on lactobacilli and the LAFA symbiotic based on lactic streptococci and lactobacilli.

The hydrogen ion concentration of the supernatant fluid differs slightly from this indicator in the LAFA (Table 5).

The differences are primarily due to the fact that the LAFA is a homogeneous mass with a high titer of microorganisms in a stable state. Culture fluid (with humidity of $100 \%$ ) is composed of dissolved metabolic byproducts, some amount of microorganisms and nutrients. When the ambient temperature changes to the level corresponding to the growth temperature, these microorganisms are further cultivated that is accompanied by the production of appropriate organic acids that determine the $\mathrm{pH}$ level.
Thus, on the basis of the conducted studies and the received data on hydrogen ion concentration (the $\mathrm{pH}$ level) of lactic acid feed additive based on various probiont microorganisms, it was revealed that the additive could be used to correct dysbioses of various etiology at cultivation and industrial maintenance of agricultural poultry. The difference in the $\mathrm{pH}$ level of the LAFAs based on various microorganisms can be a tool for the prevention and treatment of toxic poisoning and polymycotoxicoses that violate the natural $\mathrm{pH}$ level of the gastrointestinal tract.

Results of investigated ORP of the LAFA are presented in Table 6.

For comparison: the ORP of tap water is about +240 $\mathrm{mV}$, the ORP of water from artesian wellsranges from 50 to $+50 \mathrm{mV}$, while the ORP of the internal fluid of poultry is around $-70 \mathrm{mV}$. The closer the level of feed ORP and liquids entering the gastrointestinal tract, the less energy is spent by the animal on bringing them to the level of ORP of internal fluid of the body.

Like the hydrogen ion concentration, the ORPs of the studied LAFA shave stable values within the considered temperature range. The lowest ORP was noted in the LAFA-P. At a temperature of $35^{\circ} \mathrm{C}$ the ORP of the LAFA-P was $+85 \mathrm{mV}$. The maximum ORP at this temperature was revealed in the LAFA-L $(+178 \mathrm{mV})$. With the decrease of temperature, the ORP in all the LAFAs examined increased. At a temperature of $10^{\circ} \mathrm{C}$, the maximum ORP was in the culture fluid from the LAFA-L $(+225 \mathrm{mV})$, the minimum ORP - in the culture fluid of the LAFA-P $(+138 \mathrm{mV})$. Similarly to hydrogen ion concentration, the level of ORP in culture fluid of the LAFAs was mainly determined by organic acids.

The study of the ORP of probiotic feed additives showed that the effect on the course of oxidationreduction processes in the animal organism could be caused by both all types of monoculture based LAFAs and symbiotic LAFA-LS.

Table 5: The $\mathrm{pH}$ level of the culture fluid obtained from the LAFA

\begin{tabular}{|c|c|c|c|c|c|c|}
\hline \multirow[b]{2}{*}{ LAFA } & \multicolumn{6}{|c|}{ Temperature of the measured LAFA samples $\left({ }^{\circ} \mathrm{C}\right)$} \\
\hline & 10 & 15 & 20 & 25 & 30 & 35 \\
\hline LAFA-L & 4.7 & 4.6 & 4.5 & 4.3 & 3.80 & 3.60 \\
\hline LAFA-LS & 4.5 & 4.4 & 4.3 & 4.1 & 3.55 & 3.50 \\
\hline LAFA-B & 3.2 & 3.2 & 3.2 & 3.2 & 3.40 & 3.45 \\
\hline LAFA-P & 2.9 & 3.0 & 3.1 & 3.2 & 3.30 & 3.30 \\
\hline
\end{tabular}

Table 6: ORP of the culture fluid of the LAFA samples, $\mathrm{mV}$

\begin{tabular}{llllll}
\hline & Temperature of the tested LAFA samples $\left({ }^{\circ} \mathrm{C}\right)$ & & \\
LAFA & - & 15 & 20 & 25 & 30 \\
\hline LAFA-L & 10 & +213 & +211 & +210 & +200 \\
LAFA-LS & +210 & +210 & +210 & +204 & +110 \\
LAFA-B & +145 & +145 & +140 & +135 & +119 \\
LAFA-P & +138 & +138 & +138 & +125 & +111 \\
\hline
\end{tabular}


The lowest ORP less than $+100 \mathrm{mV}$ was noted in a culture fluid of the LAFA-P based on propionate acid bacteria. This largely explains the presence of bifidogenic effect on the growth of bifidobacteria and lactobacillus population.

\section{Conclusion}

The studies conducted both in vitro and in vivo showed high functional capabilities of LAFA.

A large number of feed additives, such as enzymes, vitamin-mineral complexes, hormones, etc. are widely used for the implementation of genetic potential in livestock and poultry breeding. Increasing the preservation of animals with a high population requires using antibiotics and anthelmintics.

Since 1926, when the first works of Clickner and Folwell on the use of enzymes in poultry feeding were published, up to 2012, more than 5,000 enzymes have been discovered, which are now used in various dosages, complexes and forms. Today, it is already known about the harmful effects of preparations on poultry health and the quality of the final product. Though until now, the traditional preventive and therapeutic drugs are used everywhere for all poultry population and at all emerging problems. Indications for their use, as a rule, are issued at threats of a decrease in poultry safe-keeping and productivity.

Meanwhile, in animal husbandry, the range of bioeffecting agents of next generation regulating microbiological processes in animal digestive system increases. Organic acids, probiotics and prebiotics are used increasingly. However, so far, these preparations have a minor role comparing to traditional medicines. This is partly due to the lack of immediate result in prevention and treatment of animals compared to the antibiotics and partly due to insufficiently explored properties of these additives. Determination of properties of probiotic feed additives allows embedding them in biotechnological processes into the animal and poultry organism similarly to the pharmacokinetics of therapeutic drugs. Physiological properties of the LAFA based on various probiont microorganisms, revealed in the framework of conducted scientific research, are part of biological mechanisms that can effectively affect the physiological condition of animals and poultry. Properties of the LAFA discovered and described in the present study can reduce or completely rid the poultry organism of using the whole range of preventive and curative preparations, excessive enzyme complexes, organic acids, detoxicants, etc.

The questions may arise concerning the amount of bioeffecting agents detected in the LAFA. While comparing them in terms of mathematics with traditional methods recommended for use, the comparison will not be in favor of the properties of the LAFA probiont microorganisms. But complex biological and physiological processes are generally difficult to describe mathematically, although such attempts were undertaken in biology and medicine.
This is the so-called field of quantitative biology and medicine. The most serious difficulties lie in the fact that most biological systems perform simultaneously several different functions, therefore, it is difficult to isolate both anatomically and functionally those body parts or organs which can be affected by certain preparations. An unsuccessful impact on one or another functional part of biological system can lead to an imbalance of the entire system. Thus, following the theory of optimality in biology, described mathematically, some drugs strongly affect certain components of biological structures of the body that leads to quantitative changes in the transfer function of the entire system, i.e., the organism at large.

Our studies showed that different probiont microorganisms used in the same laboratory, changed qualitatively and quantitatively the basic parameters of the final LAFA product. All the properties described in the present study are similar to the properties of the microflora microorganisms of the gastrointestinal tract, with only difference in the quantitative and qualitative composition. Small and ultra small doses of bioeffecting agents that determine the revealed properties of the LAFA can be used to create temporary microbiocoenosis, activate similar properties and capabilities of the animal body, as well as develop an adaptation mechanism, which is the basis for the normal functioning of the entire biological system.

\section{Acknowledgment}

We thank you University for supporting our work.

\section{Author's Contributions}

All authors contributed equally.

\section{Ethics}

This article is original and contains unpublished material. The corresponding author confirms that all of the other authors have read and approved the manuscript and there are no ethical issues involved.

\section{References}

Chebakov, V.N., A.N. Shvydkov, L.A. Kobtseva, N.N. Lantseva and R.Y. Kilin, 2014. Issledovaniefunkcional'nyhsvojstvmolochno-

kislojkormovojdobavki [Studying functional properties of lactic acid based feed additive]. Proceedings of the International Science-to-Practice Conference "Food, Ecology, Quality", (FEQ' 14), FSBEI Ural State University of Economics, Yekaterinburg, pp: 221-224.

Kobtseva, L.A., A.N. Shvydkov and N.N. Lantseva, 2014. Dejstviemonokul'turprobiotikamolochnokislojkormovojdobavkinasintezinterferona $\quad \alpha-2$ cheloveka $\mathrm{v}$ kishechnikelaboratornyhmyshej [The effect of probiotic monocultures of lactic acid based 
feed additive on the synthesis of human interferon $\alpha$ 2 in the intestine of laboratory mice]. Proceedings of International Science-to-Practice Conference "Integration of Science and Business in AgroIndustrial Complex", (AIC' 14), Kurgan, pp: 84-87.

Kobzeva, L.A., N.N. Lantseva and A.N. Shvydkov, 2013. Izucheniesvojstvmonokul'turmolochnokislojkormovojdobavki [Study of the properties of lactic acid based feed additive monocultures]. Proceedings of the 1st Regional Science-to-Practice Conference "Siberian Science: Problems and Prospects of Animal Products' Manufacturing and Processing Technology", (MPT’ 13), Barnaul, pp: 106-111.

Lantseva, N.N., A.N. Shvydkov and R.Y. Kilin, 2013a. EHffektivnost' probioticheskihkul'tur v sostaveprobioticheskojmolochnokislojkormovojdob avki MKD privyrashchivaniicyplyat - brojlerov [The effectiveness of probiotic cultures in the composition of probiotic lactic acid based feed additive in growing broiler chickens]. Proceedings of the 1st Regional Science-to-Practice Conference "Siberian Science: Problems and Prospects of Animal Products' Manufacturing and Processing Technology", (MPT; 13) Dedicated to $70^{\text {th }}$ Anniversary of Biotechnological Department of FSBEI Altai State Agrarian University, Barnaul, pp: 100-106.

Lantseva, N.N., A.N. Shvydkov and L.A. Kobtseva, 2013b. Realizaciya "Kodeks Alimentarius" v pticevodstve" [The implementation of "The Codex Alimentarius" in poultry]. Proceedings of International Scientific Conference, (ISC' 13), Minsk, pp: 163-167.

Lantseva, N.N., A.N. Shvydkov, L.A. Ryabukha and T.V. Usova, 2016. Fiziologicheskijehffektbiologicheskogokompleksak ormov ehksperimentahnasel'skohozyajstvennojptice [The physiological effect of biological complex of forages in experiments with an agricultural poultry]. Proceedings of the Science-to-Practice Conference of Lecturers, Students, Master and Graduate Students Dedicated to the $80^{\text {th }}$ Anniversary of Novosibirsk State Agrarian University "Urgent Problems of Agro-Industrial Complex", (AIC' 16), Novosibirsk State Agrarian University, pp: 183-187.

Ryabukha, L.A., N.N. Lantseva, A.N. Shvydkov and M.G. Sheven', 2015. Vliyaniekombinirovannyhkormovyhdobavoknasode rzhanietyazhelyhmetallov skorlupeyaicikostnojtkanisel'skohozyajstvennojpticy [Influence of combined feed additives on the content of heavy metals in poultry's egg shell and bone tissue]. Proceedings of All-Russian Youth Science-to-Practice Conference "Fundamental Bases of Contemporary Agricultural Technologies and Engineering", (ATE' 15), Yurginskiy Technological Institute of the National Research Tomsk Polytechnic University (YUTI TPU), Yurga, Tomsk, pp: 391-395.
Shkil', N.N., E.V. Filatova, V.N. Chebakov, A.N. Shvydkov and N.N. Lantseva et al., 2014. Vliyanievozrastaprobioticheskihkul'turmikroorganizmo vnaizmenenieantibiotikochuvstvitel'nostishtammovE.c oliatcc 25222 iS.enteritidis 182 in vitro [Influence of age of microorganisms' probiotic cultures on a change in the antibiotic susceptibility of E. coli atcc 25222 and S. enteritidis 182 in vitro strains]. Bull. Novosibirsk State Agrarian Univ., 3: 110-114.

Shkil', N.N., E.V. Filatova, A.N. Shvydkov, N.N. Lantseva and L.A. Ryabukha, 2016. Vliyanievozrastakul'turmikroorganizmovprobiontovnaizmenenieantibiotikochuvstvitel'nostish tammov Ent. Fecalis 200, St. Albus atcc 25923, Pr. Vulgaris 192, Kl. Pneumonia 72 in vitro [Influence of age of probiont microorganisms' cultures on change of antibiotic susceptibility of Ent. Fecalis 200, St. Albus atcc 25923, Pr. 192 Vulgaris, Kl. Pneumonia 72 in vitro strains. Bull. Novosibirsk State Agrarian Univ., 2: 128-133.

Shvydkov, A.N., V.P. Chebakov, N.H. Lantseva, R.Y. Kilin and A.L. Vereshchagin, 2013a. Issledovaniesvojstvmonokul'tur MKD priproizvodstveehkoproduktovpticevodstvabrojlerov [Studying the properties of LAFA monocultures in the production of broiler poultry ecoproducts]. Proceedings of the 10th International Science-toPractice Conference "Food, Ecology, Quality", (FEQ' 13), Russian Academy of Agricultural Sciences, Krasnoobsk, Novosibirsk, pp: 279-283.

Shvydkov, A.N., R.Y. Kilin, T.V. Usova, L.A. Kobtseva and N.N. Lantseva, 2013b. EHffektivnost' ispol'zovaniyaprobiotikov $\mathrm{v}$ brojlernompticevodstve [Utilization efficiency of probiotics in broiler farming]. Chief Zootechnician, 5: 22-29.

Shvydkov, A.N., R.Y. Kilin, T.V. Usova, L.A. Kobtseva and N.N. Lantseva, 2013c. Ispol'zovanieprobiotikov $\mathrm{v}$ brojlernomproizvodstve [The use of probiotics in broiler production]. Farm Anim. Feed. Fodder Product., 2: 40-47.

Shvydkov, A.N., L.A. Kobtseva, R.Y. Kilin, I.A. Tareeva and N.N. Lantseva, 2014a. Vliyaniemolochno-

kislojkormovojdobavkinalizocimnuyuaktivnost' V kishechnikezhivotnyh [The effect of lactic acid based feed additive on lysozymal activity in the intestines of animals]. Poultry Breed., 4: 22-25.

Shvydkov, A.N., E.A. Martyshchenko, N.N. Lantseva, V.P. Chebakov and L.A. Kobzeva, 2014 b. Issledovaniefermentativnyhsvojstvkormovyhdobavok [The study of enzymatic properties of feed additives]. Successes Modern Natural Sci., 11: 49-53. 
Shvydkov, A.N., N.N. Lantseva, L.A. Ryabukha, 2015a. Vliyaniemonokul'turmikroorganizmov-probiontov $\mathrm{v}$ sostave MKD napokazateliproduktivnosti, sohrannostiifiziologicheskoesostoyaniecyplyat-

brojlerov [Influence of monocultures of probiont microorganisms in the lactic acid based feed additive composition on productivity, safety and physiological state of broiler chickens]. Innovat. Food Security, 3: 25-32.

Shvydkov, A.N., N.H. Lantseva and L.A. Ryabukha, 2015b.

Fiziologicheskoeobosnovanieispol'zovaniyaprobio tikov, simbiotikoviprirodnyhmineralov $\mathrm{V}$ brojlernompticevodstveZapadnojSibiri. $\mathrm{CH}$. 1: Kompleksnayaharakteristikamolochno-

kislojkormovojdobavki [The physiological rationale for the use of probiotics, symbiotics and natural minerals in broiler farming in Western Siberia. Part 1: Comprehensive characteristics of lactic acid based feed additive. Monograph Novosibirsk State Agrarian University (NSAU), Novosibirsk, NSAU Information Center.
Shvydkov, A.N., N.N. Lantseva and L.A. Ryabukha, 2016. Fiziologicheskoesostoyanieiproduktivnost' cyplyat-brojlerovprivklyuchenii racionkormleniyamolochno-

kislojkormovojdobavkiiantibiotika "Bajtril" [Physiological condition and productivity of broiler chickens when included in the diet of lactic acid based feed additive and "Baytril" antibiotics]. Proceedings of the Science-to-Practice Conference of Lecturers, Students, Master and Graduate Students Dedicated to the $80^{\text {th }}$ Anniversary of Novosibirsk State Agrarian University "Urgent problems of Agro-Industrial Complex", (AIC' 16), Novosibirsk State Agrarian University, pp: 271-275. 